Northwestern University School of Law

Northwestern University School of Law Scholarly Commons

Faculty Working Papers

2009

\title{
The Number of States and the Economics of American Federalism
}

Steven G. Calabresi

Northwestern University School of Law, s-calabresi@law.northwestern.edu

Nicholas K. Terrell

Northwestern University School of Law

\section{Repository Citation}

Calabresi, Steven G. and Terrell, Nicholas K., "The Number of States and the Economics of American Federalism" (2009). Faculty Working Papers. Paper 187.

http://scholarlycommons.law.northwestern.edu/facultyworkingpapers/187

This Working Paper is brought to you for free and open access by Northwestern University School of Law Scholarly Commons. It has been accepted for inclusion in Faculty Working Papers by an authorized administrator of Northwestern University School of Law Scholarly Commons. 


\title{
The Number of States and the Economics of American Federalism
}

\author{
by Steven G. Calabresi and Nicholas Terrell ${ }^{1}$
}

In 1789 it was possible to speak of a federation of distinct States joined together for their mutual advantage, but today it is rather the Nation that is divided into subnational units. What caused this shift in focus from the States to the Federal Government? Surely the transformation from a collection of thirteen historically separate States clustered along the Atlantic seaboard to a group of fifty States largely carved out of Federal territory has played a role. Building on previous analysis of the economics of federalism, this essay considers the dynamic effects of increasing the number of states on the efficient allocation of government authority between the State and Federal Governments. When the number of States is low, the externalities imposed by state level actions are more limited-and so is the scope of Federal power. When the number increases, however, the scope of efficient Federal power expands because the States face collective action problems. In the second part of this essay, these insights from the economics of federalism are applied to the question of the optimal number of states in a federal system. Having too few states will lead to insufficient cohesion at the federal level, risking secession and ensuring weak government. On the other end of the scale, having too many states encourages the centralization of power. While the optimal number of state in a federal system will ultimately depend on geography, legal culture, and technology, the available data suggest that the ten provinces of Canada may be too few but the fifty of the US may well be too many.

What difference did it make to American federalism and constitutional law between 1791 and 1912 that the United States grew from being a federation of only 13 coequal States to being a federation of 48 coequal States? This essay will attempt to speculate about that important question - a question which has not been systematically

\footnotetext{
1 George C. Dix Professor of Constitutional Law and J.D. candidate Northwestern University 2010. We build here on the discussion in Steven G. Calabresi, "A Government of Limited and Enumerated Powers": In Defense of United States v. Lopez, 94 Mich. L. Rev. 752, 761-770 (1995). Alberto Alesina \& Enrico Sploare, The Size of NAtions (2005). See also Steven G. Calabresi, "Federalism and the Rehnquist Court: A Normative Defense ANNALS, AAPSS, 574 (Mar. 2001).
} 
analyzed so far in the otherwise extensive law review literature on federalism. ${ }^{2}$ The United States federation today with its 50 States has many more member units than it started out with and many more than do other federations around the world. Our thesis in this essay is that this is a very consequential and under-appreciated development.

In comparing federalisms around the world today, we see some federations with a relatively small number of member States or autonomous regional entities like Australia with 6 States, Belgium with 3 autonomous regions, and Canada with a land mass bigger than Americas but with only 10 provinces - a mere $20 \%$ of the U.S. total. Other federations and confederations have a middling number of State equivalents like Switzerland with 26 cantons and half cantons and the European Union with 27 member nations. India has 28 States, as well as 7 union territories administered by the Federal Government. Mexico has 31 States; Brazil has 26 States; and Argentina has 23 provinces. The United States stands outside of the pack, however, with 50 coequal federal subunits, and it reached this status early on. In 1860, at the outset of the Civil War, the United States already had 34 States, eleven of which tried to band together to secede. How would American history have been different and how would the United States be different today if the accidents of history had given us four States - one in the Northeast, one in the South, one in the Midwest, and one in the West? Would secession have worked? Would the Federal Government be a lot weaker than it is today? We seek herein to speculate on some of those questions.

\footnotetext{
${ }^{2}$ The impact of the number of states on collective action problems in federal systems has been explored by Peter H. Aranson, Federalism as Collective Action (Mar. 29, 1995) (unpublished manuscript, on file with author). For an analysis of optimal nation size, see, generally, ALESINA \& SPLOARE, supra note 1, and Robert. A. DAHL AND EdWARD R. TuFte, Size AND DEMOCRACY (1973). For a static analysis of the optimal number of states in a federal system, see, Alesina \& SPLOARE, supra note 1, ch. 9 (assuming a division of powers between federal and state governments, then determining the optimal number of states). This essay considers the inverse relationship over time: how does the number of states affect the division of powers between federal and state governments?
} 
The boundary lines of the 50 American States are mostly the result of very arbitrary and almost random occurrences. The thirteen original colonies, which successfully seceded from the federalism of the British Empire, owed their boundaries to the accident of the first settlements in British North America. The Virginia colony thus grew out of the Jamestown settlement, the Massachusetts colony grew out of the Plymouth and Boston settlements, and the other eleven of the original colonies had similar beginnings.

The most consequential decision made by the Founding Generation in this respect was the cession of all the western lands claimed by Virginia, Pennsylvania, Connecticut, and other States to the Federal Government to become the so-called Northwest Territories, which included all of the U.S. land north of the Ohio river and east of the Mississippi. This cession of the Northwest Territories to the Articles of Confederation Congress was done in part to prevent Virginia from becoming too much bigger and thus more powerful than all the other States. Critically, the Northwest Territory was carved up into what became the 6 States of Ohio, Indiana, Illinois, Michigan, Wisconsin, and part of Minnesota rather than itself being admitted just as one big State.

The carving up of the Northwest Territory into 6 States in turn set a crucial precedent for the enormous lands west of the Mississippi river which were acquired from the French Emperor Napoleon as part of the Louisiana Purchase. The Louisiana Purchase involved the acquisition of territory which today includes portions of 14 current U.S. States including all of present-day Arkansas, Missouri, Iowa, Oklahoma, Kansas, Nebraska, and parts of Minnesota, North Dakota, South Dakota, New Mexico, Montana, Wyoming Colorado, and Louisiana. The land included in the Louisiana Purchase amount 
to about $23 \%$ of the whole territory of the United States today, but it is divided among 14 States! Other important additions of territory followed especially as a result of the Mexican War, the Gadsden Purchase, the Alaska Purchase, and the annexation of Hawaii, while some territories held in 1787 like Kentucky, Tennessee, Vermont, and Maine all were admitted as additional individual States in their own right.

Indeed, as early as 1820, only 31 years after the Constitution had gone into effect, the United States had 22 States - almost twice as many as it had started with. From that time on, the only controversy about adding States was about keeping equal the numbers of new slave and free States. By the outbreak of the Civil war in 1861, the Union was up to 34 States and by 1913, when the federal structure of the national government was radically altered by the additions of the $16^{\text {th }}$ and $17^{\text {th }}$ amendments authorizing the federal income tax and providing for the direct election of senators, the Union had 48 States. The critical point is that the Framers concern that Virginia not be too much larger than the other 12 original States led to a national policy of creating numerous new States out of territories rather than a few big ones. It is for this reason that we today have fifty States rather than say twenty and that is a fact that is very consequential.

This essay will theorize about the likely effects of going from a small number of States confederation of 13 States to a large number of States confederation of 48 States in 1913 in light of the economics of federalism. In previous writing, Professor Calabresi has written about some of the economic policy arguments for empowering the national government and some of the economic policy arguments for empowering the State governments. ${ }^{3}$ What effect is there on each of these arguments when you go from a

\footnotetext{
${ }^{3}$ Steven G. Calabresi, "A Government of Limited and Enumerated Powers": In Defense of United States v. Lopez, 94 Mich. L. REV. 752 (1995).
} 
small State federation of 13 to a numerous State federation of 48 ? What implications does the American experience imply for federalism in Australia, Canada, Germany, Belgium, Switzerland, and the European Union? Part I addresses the question of how increasing the number of States affects the economic case in favor of empowering the Federal Government. Part II addresses the question of how increasing the number of States affects the economic case in favor of empower the States. Part III considers the question of whether any meaningful kind of federalism is even possible once the number of States increases beyond a certain point. Put another way, what is the optimal number of States that a federation ought to have if one wants to maintain a balance between national and State power so as to benefit from the economics of federalism.

\section{The Number of States and the Case for Augmenting National Power}

This section will argue that the United States' move from 13 States at the Founding to 48 by 1913 greatly strengthened the public choice, economics of federalism case for augmenting national power. We will discuss a number of economics of federalism arguments that are commonly made for empowering the Federal Government, and we will show that all of those arguments become more compelling as the number of States in a federation goes up. We begin with collective action problems and end with problems of pluralism and civil rights.

\section{A. Collective Action Problems}

1. War and Foreign Affairs 
The most compelling argument in American history for empowering our national government has been the need to overcome collective action problems. All of Britain's colonies in 1776 faced such a collective action problem when Americans demanded the right to be represented in Parliament if they were going to be taxed and only some parts of the British Imperial Federation were able to band together to secede. Notably, the British North American colonies in Canada chose not to leave the Empire at that point. The 13 States which did band together collectively to secede from Britain in 1776 quickly realized that they were having a lot of difficulty acting together to win the Revolutionary War and then to protect themselves from foreign enemies in the 1780's. A principle argument for writing the Constitution in 1787 was that a stronger Federal Government was needed for defense or foreign policy reasons. Many feared that the 13 States acting collectively would be unable to defend themselves from being reacquired by Britain or being seized by some other European Empire.

The need to defend against a foreign enemy or to win a war, once one has started, has always led in American history to the augmentation of national power. National power emerged and grew in the 1770's and 1780's out of a need to cooperate against Britain, it expanded enormously during and after the Civil War, and it then again grew enormously during World War II such that national wage and price controls came to be thought of as within the scope of federal power. Federations start as mutual defense pacts to solve a collective action problem, and Federal Governments grow in power in response to foreign threats.

Foreign threats are not, however, the only military collective action problem which federalism protects against. Another collective action problem that federations 
face is warfare among the members of the federation. In the 75 years between 1870 and 1945, the peace and harmony of Western Europe was interrupted by three FrancoGerman Wars: the Franco-Prussian War, World War I, and World War II. This is a collective action of the most destructive and ruinous kind. The modern day federation of the European Union began and has been built in part to end such warfare on the European Continent, and the EU along with the North Atlantic Treaty Alliance has done that.

Many founding generation Americans feared in the 1770's and 1780's that there might emerge two or three federations with shared land boundaries in the area that is now the United States and that warfare might erupt among them along with a need for standing armies and a concomitant loss of liberty. ${ }^{4}$ Some Framers believed that the English tradition of liberty was in part a product of the fact that Britain, as an island, had no need for a standing army to defend itself relying instead on its navy. Sailors are less numerous and less of a threat to domestic liberty than are soldiers. Abraham Lincoln thought that one of the many reasons why it was vital to keep the Union together was to avoid the prospect of future warfare between the Confederacy and the North over things like access to the Gulf of Mexico from the Mississippi River through the port of New Orleans. $^{5}$

Civil war between States or Provinces or warfare between neighboring countries is the ultimate collective action problem, and it is averted by enhancing the power of national and transnational entities. This is a principle argument as to why it is often desirable to enhance national and transnational power. How then does increasing the number of States from 13 in 1790 to 34 in 1861 and to 48 in 1913 affect the collective

\footnotetext{
${ }^{4}$ Akhil Reed Amar, Some New World Lessons for the Old World, 58 U. CHI. L. REV. 483 (1991).

${ }^{5}$ Id.
} 
action problem of providing for a common defense and protecting against civil warfare? Let's start with the problem of providing for the common defense.

A loose confederacy of a very small number of States - say four - would face very low costs in organizing defense against specific enemies and threats and so it would have less of a need to delegate broad and permanent defense powers to a national or transnational entity than would a confederacy with more member States. As the number of members States goes up from 4 to 13 to 34 and then to 48 the costs of organizing against each specific threat as it arise increase exponentially and the need for a permanent central national or transnational entity increases. ${ }^{6}$ It is a lot harder and more expensive to coordinate 48 armies, navies and foreign policies than it is to coordinate 4 or even 13 . Washington found coordinating 13 State militias during the Revolutionary War and its aftermath to be so exasperating that he led in the effort to draft the U.S. Constitution so that future Americans would never face that problem instead.

The State militias survived ratification of the Constitution until 11 of the 34 of them seceded in 1860 and 1861 and fought the other 23 which styled themselves as the Grand Army of the Republic. The militias were folded into the National Guard and subordinated and this may well have become essential once the number of State militias increased from 13 at the Founding to 34 in 1861. One would expect that as the number of States increased from 13 to 34 it would become more and more costly to leave anything of a military or foreign policy sort (like the militias) under State control because of the escalating costs of collective action. It is thus entirely predictable that the State

\footnotetext{
${ }^{6}$ See R.H. Coase, The Problem of Social Cost, 3 J.L. \& Econ. 1, 16-17 (1960) (on the firm as solution to externalities in the presence of transaction costs); R.H. Coase, The Nature of the Firm, 4 EconOMICA 386 (1937) (on the firm as a solution to transaction costs).
} 
militias would be forced to fade into irrelevance after 11 of them were so impertinent as to wage war against the other 23 .

What about the effects of an increasing number of States on the likelihood of an outbreak of a civil war and on its prospects for success? Here increases in the number of States cut in both directions. On the one hand one would expect that 34 States in 1861 would have more profound disagreements and controversies among themselves than 13 States would have had in 1790. If you multiply the number of States who are actors, there are bound to be more disagreements among those States. Moreover, a few of the States - think South Carolina during the Nullification Crisis - are bound to take positions that are especially provocative and extreme. Thus, a federation with a lot of States will likely have a few that are real outliers like today Louisiana, Vermont, and Utah. In this respect, increasing the number of States and making each State smaller will facilitate factional capture of a State and the taking of extreme positions.

The flip side of the coin, however, is that increasing the number of States also creates a severe collective action problem for any would-be seceders. ${ }^{7}$ A successful secession in the face of military resistance requires that a very large percentage of the States with a large percentage of the federations population and wealth participate in the secession. Consider here the collective action problem that helped to forestall southern secession during the Civil War.

In 1861, there were 15 slave States in an area that today has 16 States: Alabama, Arkansas, Delaware, Florida, Georgia, Kentucky, Louisiana, Maryland, Mississippi, Missouri, North Carolina, South Carolina, Tennessee, Texas, and Virginia. In addition,

\footnotetext{
${ }^{7}$ See Barry R. Weingast, The Economic Role of Political Institutions: Market Preserving Federalism and Economic Development, 11 J.L. ECON. \& ORG. 1, Part 2.1 (the Sovereign-Constituency Transgression Game with repeated interactions).
} 
slavery was legal in the District of Columbia, in the territorial area that became Oklahoma, and in parts of the Nebraska Territory. The number of slave and free States was deliberately kept even until 1858 so as to ensure an equal number of pro-slavery and pro-freedom senators. In 1860 and 1861, only 11 of the 15 slave States seceded while four - Delaware, Kentucky, Maryland, and Missouri - did not leave the Union. The nonsecession of those four slave States coupled with federal control over the District of Columbia and all the Territories may well have been indispensible to the North's victory. In addition, one of the slave States which seceded -- Virginia - split in two with the free counties becoming the new pro-Union State of West Virginia. Thus of the 16 States now in the geographical area where slavery was legal in 1860 almost one third of them - five States - did not secede.

This may well be a collective action problem which doomed the Confederacy. As late as the summer of 1864, Abraham Lincoln was behind in his bid for re-election because the North had not won a bitter war. How much worse would things have been for the Union if Delaware, Kentucky, Maryland, Missouri, not to mention the District of Columbia, Oklahoma, and Kansas had all joined forces against a Union government with its capital in say New York City which was besieged with anti-draft riots? A good case can be made that the Confederacy was done in by the high cost of organizing secession among so many different legal actors. The Confederacy came a lot closer to succeeding than South Carolina did during the Nullification Crisis because 11 of 34 States - one third of the total - were defying federal power, but that was not enough.

Consider the costs of collective action and what American politics might look like today if we had only 4 States instead of 50: the Northeast, the South, the Midwest, and 
the West. Having lived in three of these four regions and having observed the distinctive regional subcultures, I think we would have serious regional secessionist movements if the accidents of history on the number of States had happened differently. The divide between red and blue State America in presidential elections shows among other things a continuing sharp split between the South and the Northeast plus the Pacific Coast. If we had four States instead of 50 and if State lines corresponded to the regional divisions I just mentioned, we think there might be serious talk of secession and moreover that the Federal Government would be much less powerful and would be kept by the 4 regional superstates on a very short leash.

Those who doubt me on this need only look at Canadian or Belgian federalism. Canada is bigger than the United States but has only 10 Provinces instead of 50 one of which is French speaking Quebec. Quebec is populous and large, and in the 1990's a referendum of secession was defeated there only by a margin of $50.6 \%$ opposed to $49.6 \%$ in favor. The Canadian Supreme Court has ruled that Quebec has a constitutional right to secede albeit not unilaterally and not without negotiations with the Federal Government in Ottawa. ${ }^{8}$ The drawing of provincial boundary lines to correspond with linguistic, ethnic, and religious cleavages makes Quebec Province very different from all of the other 9 Provinces. Imagine how peaceful Canadian politics might be if Canada had 50 Provinces instead of 10? Imagine the benefit of provincial boundary lines that were arbitrary and random the way U.S. State boundary lines are and which cross-cut the linguistic, ethnic, and religious cleavages.

Now consider another non-democratic federation which recently split apart with 15 sub-national units. I refer of course to the former Soviet Union which had 15

\footnotetext{
${ }^{8}$ Reference re Secession of Quebec, 2 S.C.R. 217 (Supreme Court of Canada 1998).
} 
Republics only one of which is the current Russian Federation. The so-called Constitution of the former U.S.S.R. had a grandiose Bill of Rights guaranteeing liberties of all sorts, and it also guaranteed a right of secession. No provision of the U.S.S.R.'s constitution was ever followed other than the secession clause. Why were nations like Ukraine which had been Russian for hundreds of years able to achieve independence from a nuclear armed communist dictatorship? With only 15 member Republics, many with their own histories and dialects or languages covering the largest geographical area of any nation on earth, the cost of collective secessionist action were simply not that high. Had the U.S.S.R. been a 50 State federation it would probably still be around today.

Consider here the successful secession of the 13 American colonies from the British Empire in 1776. There were major costs to this collective action, as mentioned above, and General George Washington almost lost the war because of the weakness of the central government under the Articles of Confederation. Britain tried to direct its ire prior to the war at only the tax rebels in Massachusetts in the hopes that it could divide them from the other colonists. The so-called Intolerable or Coercive Acts in 1774 were targeted only at Massachusetts, but by then Britain had tried to impose a Sugar tax, a Stamp tax, and a tax on tea on all 13 colonies so they all came to Massachusetts' side. The colonies in the end overcame the collective action problem of uniting to secede from the British Empire in part because they were so different from Britain and had so much in common with one another.

Another successful secession occurred on January 1, 1993 when the Slovak people dissolved their union with the Czech people even though the differences between the two peoples are vanishingly small. The fact Czechoslovakia dissolved so easily is no 
doubt attributable in part that it consisted of only two peoples each living in geographically defined areas rather than 50 peoples living comingled with one another. This made the cost of secessionist action by the Slovaks very low.

Low secession cost also led at this time to the dissolution of the 6 Republic federation of Yugoslavia. Under Marshall Tito, its formidable and moderate longtime communist dictator, Yugoslavia had seemed to be a model of inter-ethnic tolerance but with Tito's death it dissolved fairly swiftly and violently. The fact it had only 6 Republics rather than say 25 or 50 and that each Republic, like Quebec, contained a territorially homogenous ethnic, linguistic, or religious group made Tito's federation much more unstable than any realized. The violent dissolution of Yugoslavia calls to mind the partition of British India into Pakistan and Hindu India in 1947 and the partition of Ireland into Protestant Northern Ireland and the Catholic Republic of Ireland in 1921. Here again the division of the population into two main groups - Hindus and Moslems in India and Catholics and Protestants in Ireland - greatly lowered the cost of collective secessionist action.

A similarly low cost to collective action has led to serious devolution movements in Belgium, the United Kingdom, Spain, and France. Belgium has devolved tremendous power to its Flemish and Walloon communities, and it seems quite possible it will peacefully dissolve as did Czechoslovakia. The United Kingdom recently devolved some power to Scotland and Wales, and the movement for Scottish independence still remains a real threat to the U.K. even though the countries have had the same executive since 1603 and the same parliament since 1707. The division of the British island into two peoples - the English and the Scots - may prove as unstable as the division of 
Czechoslovakia into Czechs and Slovaks. Spain faces similar problems with Catalonia and the Basque Region, while France has to deal with a terrorist secessionist movement on the island of Corsica.

American history offers two examples of unsuccessful secessionist pressure by one State acting only. Since these examples are instructive, we will briefly discuss them. In the 1780's tiny Rhode Island boycotted the Philadelphia Convention that wrote the Constitution and it then refused to ratify the Constitution all for fear the new Federal Government would tax its wealthy merchants. For similar reasons, Rhode Island had earlier been the lone State to veto an amendment to the Articles of Confederation that would have given Congress the power to regulate and tax commerce. The Articles of Confederation could only be amended by all 13 colonies acting unanimously. Rhode Island thus tried to block ratification of the Constitution by denying its consent. The other States, however, called Rhode Island's bluff. By the Spring of 1990, President Washington had the new Federal Government up and running under the Constitution without Rhode Island but with all 12 of the other 13 original States. Washington declared that he would start imposing customs duties on all trade between the U.S. and Rhode Island and the States wealthy merchants panicked and backed down. Rhode Island ratified the Constitution by one vote on its third try in 1790 .

A second example in American history of a single State failing in rebelling against the Federal Government came with South Carolina's effort to nullify a high federal tariff in the Nullification Controversy of 1832. South Carolina called a special convention analogous to the convention that had ratified the Constitution and that convention adopted an ordinance declaring the federal tariff null and void within the 
territorial confines of South Carolina. President Andrew Jackson issued a proclamation declaring South Carolina's ordinance unconstitutional and Congress passed a Force Bill authorizing President Jackson to use military force to subdue South Carolina if necessary. South Carolina caved and repealed its ordinance of nullification, but it learned that the next time it wanted to challenge federal power, which turned out to be in 1860, it would need to seek allies from among the other States. In 1832, there were only 24 States in the Union 12 of which were slave States whereas in 1860 there were 34 States in the Union only 15 of which were slave States. The logic of collective action suggests that South Carolina waited too long to try to organize a secession. ${ }^{9}$

The Nullification Controversy was foreshadowed in 1798 by the Virginia and Kentucky Resolutions whereby the two States - led by Thomas Jefferson and James Madison - tried to declare that the newly passed federal Alien and Sedition Acts were unconstitutional. The Resolutions claimed the States had formed the Union and that they could interpose themselves against unconstitutional assertions of federal power. Rhode Island passed a resolution disagreeing and claiming that the federal Constitution was only to be enforced by the federal courts. The controversy was taken to the American people in the election of 1800, and Jefferson was elected President while his allies won control of Congress. As a result, the Alien and Sedition Acts died with Jefferson pardoning those convicted under them.

Our conclusion then is that the case for enhancing federal power over war-making or foreign affairs becomes stronger as the number of member states in a federation increases. We also conclude that the likelihood of a successful secession or civil war

\footnotetext{
${ }^{9}$ See Mancur Olson, JR., The Logic of Collective Action: Public Goods And The Theory of GROUPS (1965) (while secession may itself seem an excludable good, there remains the possibility of free riding by States who hold back their support until the likely outcome of becomes discernable).
} 
decreases sharply as the number of member states in a federation increases. This is especially the case if state boundary lines are drawn arbitrarily as they were in the U.S. rather than territorially to empower a linguistic, ethnic, or religious subgroups as they were in Canada, the U.S.S.R, or Yugoslavia.

\section{Free Trade}

In addition to winning wars and formulating a foreign policy, all countries have a strong national interest in trading with one another. International trade by definition leaves both sides better off, and it increases GDP in both of any two countries that engage in it. Unfortunately, all governments need revenue to function and taxes on international trade are often a politically popular way of raising money because powerful local economic interests may want to be shielded from foreign competition. Even aside from revenue raising tariffs, governments may find themselves besieged with requests from politically powerful local interest to ban certain imports altogether. Without coordinated action, therefore, governments often find themselves with mutual bans on trade that hurt everybody concerned. Overcoming these bans on trade and acquiring access for ones products to foreign markets requires that a government negotiate a free trade treaty with another country or countries. This is a costly and time consuming endeavor.

The 13 original American colonies did not have to worry about free trade or foreign markets in which to sell their products prior to 1776 because they were part of the free trade system of the British Empire. After independence and in the 1780's, however, America found itself without access to British or French markets, and the Federal Government under the Articles of Confederation lacked the constitutional power to make 
treaties permitting trade with foreign power. The 13 States on their own lacked the leverage to negotiate such treaties. Efforts were made twice to amend the Articles to give Congress this power, but the first effort was vetoed by Rhode Island and the second by New York. A principle reason therefore for the writing of the Constitution was to give Congress the power to regulate trade and economic relations with foreign countries.

The universal need for free trade thus turns out to be second only to the need for mutual defense associations as a reason for the creation of national federal or international governing entities. As the number of member States in a federation goes up from say 13 to 34 or 48, one would expect the need for delegation of power to negotiate trade agreements to federal or confederal governments to go up exponentially as well. If even the 13 original American States needed a central government to negotiate trade treaties then surely the 50 American States today need that central government even more badly.

This point is augmented by the fact that federations need free trade domestically among their member States as well as with foreign countries. The Federal Government thus acquired in 1789 a power to regulate domestic interstate commerce which Congress had lacked under the Articles of Confederation. As the number of member States in a federation goes up from 13 to 34 to 48, the need for a central government with the power to protect domestic free trade goes up exponentially as well. Imagine the cost and time it would take for each of the 50 States today to negotiate a free trade agreement with all of the 49 States other than itself? The need for free trade both with foreign nations and domestically is so powerful that many sovereign nations have entered into free trade pacts with their neighbors or in the case of the European Empires with their colonies 
which pacts are enforced by some kind of confederal governmental structure. The European Union is one such structure and GATT may well be becoming another. Again, the greater the number of member States in a federation, the more the need for federal or confederal centralized governmental power.

One would thus expect that as the number of members of a federation increases the amount of regulation of interstate commerce and the scope of the Federal Government's power over interstate commerce would increase as well. This, of course, is exactly what has happened in the United States. We started out in 1790 with only 13 States and from that time until the Civil War, Congress passed almost no laws exercising its commerce power which power was mainly enforced in the Supreme Court's dormant commerce clause caselaw about which we will say more below. Arguably Congress's first major exercise of its power to regulate interstate commerce came in 1887 with the passage of the Interstate Commerce Act and the creation of the Interstate Commerce Commission. Three years later, in 1890, Congress passed a second major statute regulating interstate commerce, the Sherman Antitrust Act. In 1887, there were 38 States in the Union and by the end of 1890 , there were 44 . Obviously, the causes of the passage of these federal statutes are complex and various, but it must have been far easier for Congress to regulate interstate commerce in a Union of 44 States rather than a Union of 13 in 1790.

The Supreme Court dramatically expanded its doctrinal understanding of the scope of federal power under the Commerce Clause in the 1903 case of Champion v. Ames $^{10}$ which was handed down at a time when there were 45 States. Champion is of critical importance because it upheld regulations of interstate commerce enacted for

${ }^{10} 188$ U.S. 321 (1903). 
moral rather than free trade promoting purposes. The statute upheld in Champion regulated the interstate shipment of lottery tickets. In the wake of Champion, Congress passed federal morals law governing interstate commerce in prostitutes and in harmful food and drugs. Champion opened the door to what has proved to be an explosive growth in the federal police power.

By 1912, the Union had added another three States and was up to 48 members. A year later, the $16^{\text {th }}$ Amendment giving the Federal Government the power to tax incomes without apportionment among the States was ratified. The $16^{\text {th }}$ Amendment, coupled with a federal police power under Champion v. Ames, spelled the death knell of American federalism. Before 1913, the Federal Government was dependent on the tariff for revenue, but the $16^{\text {th }}$ Amendment changed that opening vast sums of money for federal use. Since Congress has almost unlimited power to attach strings to federal funds under the Constitution, increasing the Federal Government's revenue enormously meant an enormous increase in its power as well. By the 1920's, even conservative Republican Congresses and Presidents were spending federal money to promote maternal and infant health. The leap from this to spending federal funds for social security or welfare was only one of degree and not of constitutional dimension.

The Supreme Court did make a famous and much discussed effort to cabin the Commerce Clause in $\underline{\text { Hammer v. Daggenhart }}^{11}$ and in several cases in the 1930's where it struck down key New Deal legal initiatives. The line the Court tried to draw was one that would allow Congress to regulate the flow of harmful goods across State lines but not harmless goods like the cotton goods manufactured with child labor in Hammer v. Daggenhart. The obvious objection to this line was that if there was no free trade zone

${ }^{11} 247$ US 251 (1918). 
created by the federal Commerce Clause then goods made with child labor would encounter customs barriers when they crossed State lines. Instead of those customs barriers, such commerce encountered the public policy of the United States as established by federal law. ${ }^{12}$ It is an unanswerable objection. Indeed, at about the same time it was deciding Hammer the Supreme Court was upholding federal power in the Shreveport Rate cases to regulate rates on wholly intrastate railroad rates where such regulation had a substantial effect on interstate commerce. The $\underline{\text { Shreveport Rate cases }}{ }^{13}$ lead inexorably to the conclusion that the Supreme Court reached in 1937 in Jones \& Laughlin Steel ${ }^{14}$ that Congress can under the Commerce and Necessary and Proper Clause put together regulate all wholly intrastate activities that substantially affect interstate commerce. The Court in this case upheld the federal labor laws which were regulations of the conditions of manufacturing. A few years later $\underline{\text { United States v. Darby }}{ }^{15}$ overruled Hammer v. Daggenhart, and State power bit the dust.

What should we make of the fact that even after the ratification of the $16^{\text {th }}$ Amendment in 1913 the Supreme Court resisted federal power in Hammer v. Daggenhart in 1918 and in a couple of cases striking down New Deal statutes? Not very much because Hammer itself was an Indian summer of the old order. There was another federal constitutional amendment adopted in 1913, one year after the Union expanded to 48 States, that drove yet another nail into the coffin of State power. We refer, of course, to the ratification in 1913 of the $17^{\text {th }}$ Amendment which ended direct election of senators. This totally transformed the Senate from being a kind of U.N. Security Council of

\footnotetext{
${ }^{12}$ Id. at 277 (Holmes, J, dissenting).

${ }^{13}$ Houston E. \& W. T. Ry. Co. v. United States, 234 U.S. 342 (1914).

${ }_{15}^{14}$ NLRB v. Jones \& Laughlin Steel Corp., 301 U.S. 1 (1937).

${ }^{15} 312$ U.S. 100 (1941).
} 
ambassadors from the several States into its being an arm of the national government as well. That transformation was made possible in part because the expansion from 13 in 1790 to 34 in 1860 to 48 States in 1912 had the necessary effect of increasing the number of Senators from 26 to 68 to 96 . A 26 member Senate elected by the State legislatures was small enough to be a real check on national power. A 96 member Senate was not. Moreover, by 1912 only 15 States had originally been independent countries - the original 13 plus Texas and arguably California ${ }^{16}$ while 33 had been carved out of federal territory. The very fact the $17^{\text {th }}$ Amendment could be rammed down the throat of a Senate elected by State legislatures was proof of how dead federalism had become. By 1913, the Federal Government was constitutionally omnipotent, as Missouri v. Holland would begin to show.

So why Hammer v. Daggenhart and its taxing power companion, Bailey v. Drexel Furniture? ${ }^{17}$ Because it took time for the nine Supreme Court justices who had been picked in part by a federalist pre- $17^{\text {th }}$ Amendment Senate to be replaced by more nationalist Supreme Court justices picked by a post $-17^{\text {th }}$ Amendment Senate. The first justice appointed after these momentous events was Attorney General James McReynolds whose conservative pro-State power views had been shaped by a lifetime growing up in a different Union from the one the United States had become. McReynolds, of course, became one of the four conservative justices on the Court of the 1930's who were referred to as the four horsemen of the apocalypse.

The lag in Supreme Court turnover was augmented by the fact that conservative presidents William Howard Taft and Warren G. Harding got to fill 10 vacancies on the

16 California claims to have been independent but was so only briefly during the Mexican War.

17259 U.S. 20 (1922). 
Supreme Court while holding the White House for 7 years while progressive Presidents Theodore Roosevelt and Woodrow Wilson got only 6 vacancies despite holding the White House for more than twice as long -15 years. The Supreme Court that struck down a lot of New Deal laws between 1933 and 1937 on a 5 to 4 vote had no appointees of Franklyn Delano Roosevelt on it. Three of the five justices who voted with the majority in Jones \& Laughlin Steel in the famous switch in time that helped to save nine were appointees of Republican Herbert Hoover while one was an appointee of Republican Calvin Coolidge. Only one of the five justices who made the switch in time that saved nine was appointed by a Progressive President. In contrast, three of the four Jones \& Laughlin Steel dissenters were Harding appointees while one was Wilson appointee McReynolds. Our conclusion is that Hammer v. Daggenhart and the Indian summer of the constitutional order of dual federalism were the result only of a lag before the nationalizing effects of the $16^{\text {th }}$ and $17^{\text {th }}$ Amendment could be felt.

Yale Law School Professor Bruce Ackerman has famously argued that American constitutional history is usefully divided into three regimes: the Founder's Republic, the Middle Republic, and the New Deal Republic with constitutional moments and change occurring in 1789,1868 , and $1937 .^{18}$ There is a case to be made for Ackerman's periodization based on Supreme Court doctrine (if one thinks it is worth the paper it is published on which we do not). In fact, Ackerman is right that we have had three regimes with respect to the scope of federal power, but the key fact one needs to know is that the Union had 13 States in 1790, 34 in 1860, and 48 in 1913. The increase in the number of States first made southern secession too expensive to organize as a matter of collective action, and it then made any residual claims of State power and dual federalism

${ }^{18}$ Bruce Ackerman, We the People: Foundations (1991). 
impossible to maintain during the Progressive era. There was a Rooseveltian transformative presidency but it was Republican Theodore Roosevelt and not his Democratic cousin who created the political climate that led to the $16^{\text {th }}$ and the $17^{\text {th }}$ Amendments' obliteration of dual federalism. Our three transformational presidents are Federalist George Washington and Republicans Abraham Lincoln and Theodore Roosevelt. FDR just piled on for the ride.

\section{B. Externalities}

Another commonly mentioned problem that favors national or transnational power is a need for a national or transnational entity that can stop State or Provincial laws that generate serious negative externalities for other States. ${ }^{19}$ A classic example of such a negative externality might be the emission until recently into the air of pollution by Midwestern manufacturing States which caused acid rain in New England thus killing trees. States generating such negative externalities might have little political incentive to correct them because the States own citizens may benefit from manufacturing the costs of which are felt mainly by out-of-staters with no vote in the manufacturing States' elections.

How would the expansion from 13 States in 1790 to 34 States in 1860 to 48 States in 1912 affect the externality correcting case for the enhancing of national power? Obviously, a greater number of States will generate a far greater number of externalities. As it happens, 48 is four times 13 but of course the number of externalities will increase exponentially. It is thus entirely predictable that federal power would grow steadily as

\footnotetext{
${ }^{19}$ See Jacques LeBoeuf, The Economics of Federalism and the Proper Scope of the Federal Commerce Power, 31 SAN DIEGO L. Rev. 555 (1994).
} 
the number of States increased, first with the emergence in the Founders' Republic of the dormant commerce clause and of federal common law and then with the emergence during the Middle Republic of the Sherman Antitrust Act, the Interstate Commerce Commission, federal paper money in peacetime, federal rules sanctioning polygamy, and a federal police power for interstate gambling, prostitution, or shipment of impure food and drugs. The post 1913 Progressive Republic with its 48 States has seen Federal Government power mushroom exponentially to the point where the growth of 6 marijuana plants in one's own home is a federal crime because of the harmful external effects that growing those plants is said to have on other States.

The greater the number of States, the greater the number of externalities, and the larger the role of the federal or confederal government. In theory, confederations could negotiate solutions to externalities with one another just as they could all adopt codes of uniform State laws. In practice, the costs of negotiating such collective action become prohibitive once the number of federal subunits becomes too large. As a result, federations with a lot of federal subunits will have very powerful federal or confederal governments.

Canada with 10 Provinces, Germany with 16 States called Laander, Australia with 6 States, Switzerland with 26 cantons or half cantons, as Swiss States are called, and the European Union with 27 member nations have all been able to maintain some meaningful limits on federal or confederal power. The United States was able to do the same as late as 1860 when we had as many as 34 States. But once one gets to that large a number of federal subunits, the increase in the number of externalities and the power of the States to defend their power from national expropriation begins (as Karl Marx might say) to 
whither away. We shall return below to the question of what is the optimal number of States for maintaining dual federalism, but we strongly suspect that the U.S. surpassed that magic optimal number a long time ago. The U.S. federation of 50 States has an essentially omnipotent Federal Government.

There is a school of thought which suggests that there are political safeguards for State power in the U.S. because the States draw boundary lines for U.S. House districts, elect senators by State, and elect the President and Vice President through the federalist mechanism of an Electoral College. As a practical matter, however, the States are so dependent on federal appropriations and on the income tax subsidy for State and local taxation which is created by making such taxes deductible from federal income taxes that the Federal Government is omnipotent. There is no area of law - not family law, not tort law, not education, not health care, not criminal law, not obscenity law, not religion clause law, and not abortion or gay rights law - where the Federal Government does not have the last word either through Congress or the Supreme Court. The Federal Government has in recent times established a 55 mile per hour speed limit and a national drinking age of 21 instead of 18 . There is nothing of importance which is decided anymore in the U.S. at the State level.

One symptom of that is the gradual incorporation of the Bill of Rights and of natural and inalienable rights into Section 1 of the Fourteenth Amendment to constrain State action. The first incorporation case involved the Takings Clause of the Fifth Amendment and occurred in 1897 when the Union had already grown to include 45 States. $^{20}$ By 1905, the Supreme Court in Lochner v. New York ${ }^{21}$ imposed substantial

\footnotetext{
${ }^{20}$ Chicago, B. \& Q. R. Co. v. Chicago, 166 U.S. 226 (1897).

${ }^{21} 198$ U.S. 45 (1905).
} 
additional national constitutional constraints on State power. The rest of the Bill of Rights beyond the Takings Clause was incorporated in the period between $1925^{22}$ and $1969^{23}$ when the Union was up to 48 or 50 States. Unenumerated, national, natural law rights were judicially enforced in the economic arena from 1905 to 1937 and then with respect to personal, non-economic matters from 1965 to the present. For the last 104 years, critics have complained that national rights creation by the U.S. Supreme Court infringes on State power, reduces competition and experimentation, and is a usurpation of power by the high Court. This criticism, loud and persistent though it has been, has proved to be completely ineffectual. Once the number of federal subunits hit 45 in 1896, 48 in 1912, and 50 in 1959, the creation of a national human rights law was probably unstoppable. Incorporation and substantive due process were probably inevitable once the number of federal subunits hit 45 . In retrospect, the federal ban on polygamy in Utah was a forerunner of what was to come.

There is one respect in which federal elimination of State caused externalities diminished as the number of States increased and that is with respect to less vigorous enforcement of the dormant Commerce Clause, the elimination of the Supreme Court's role through federal common law in creating a uniform federal commercial law, and the establishment during the New Deal of a more State friendly standard for federal preemption of arguably conflicting State laws. These developments do not, however, respect a new found desire to empower the States so much as they reflect a federal policy of encouraging socialism and rent seeking behavior. We will have more to say below

${ }^{22}$ Gitlow v. New York, 268 U.S. 652 (1925).

${ }^{23}$ Benton v. Maryland, 395 U.S. 784 (1969). 
about why increasing the number of federal subunits would have been likely to encourage State efforts to get Washington to enable and enforce cartels.

\section{Economies of Scale}

Another economic argument for national or international power is that as to some activities there are economies of scale that are gained if they are done once by a national or international government rather than 50 times by State governments. We think it is self evident that there are economies of scale for example that are gained by letting the national government create an air force, a space program, and a medical science research program through the National Institutes of Health none of which are authorized as enumerated powers of the national government. This is why Britain, France and Germany chose not to create their own space programs but instead pooled their efforts into a trans-European space program. Less is not always more, and sometimes bigger is better. This is why national grocery market chains have largely replaced corner grocery stores. The advantage of national and international governmental entities is that they can realize economies of scale that the 50 States might not be able to take advantage of.

So how does increasing the number of States from 13 to 34 to 48 affect this economic normative argument in favor of enhanced national power? Imagine here the difference between a United States with four States - the Northeast, the South, the Midwest, and the West - as compared with the current 50 State structure. A federation with 50 subunits rather than 4 will be more likely to experience economies of scale from enhanced national power. A federal subunit consisting of the Northeast or the West might well fund its own stem cell research program, for example, when the State of 
Massachusetts acting alone would not undertake that. California today has its own global warming and environmental policies, for example, in part because it has about one ninth of the total population of the United States, it is geographically the third largest of the 50 States, and it has an economy that would be the seventh largest in GDP in the world if California were an independent sovereign nation. Carving the territory of the United States into 50 rather than 4 subunits inevitably means more activities as to which there are economies of scale from doing things federally, and it therefore means a more powerful Federal Government.

In theory, of course the States could negotiate to undertake joint activities and thus to realize economies of scale. To some extent the States do that when with federal permission they create regional airport authorities and other such entities. The problem again is that the bigger the number of federal subunits the higher the cost of collective action. And, the higher the costs of collective action, the greater the incentive to just empower the Federal Government and let it handle the problems in question.

This point, in conjunction with the other points about the escalating costs of collective action as the number of territorial subunits increases, suggests that the prospects for the success of the European Union may be bright indeed. The EU already has 27 member nations and the line of nations wanting to join remains. An EU with 27 member nations will often experience economies of scale by doing things itself rather than leaving them to be done by Germany, France, or the U.K. alone. Moreover, there will be lots of externalities eliminated by EU action, and a diminished ability of any one of the 27 member nation States to threaten credibly to secede or play holdout. The EU is fast approaching the 34 State threshold the U.S. experienced in 1860 when the South 
discovered that the costs of collective secessionist action had become prohibitively high. If conservative elements of the Tory Party in the U.K. were to regain control of the Prime Ministers office and of Parliament could they ever withdraw from the EU or nullify an EU policy? We doubt it although it might well be wise for the U.S. to offer the U.K. membership in NAFTA if such a State of events were to occur.

The bottom line is that increasing the number of member subunits in any federation or confederation obviously increases collective action costs thus leading to enhanced national power. The key therefore to understanding the changes in American constitutional federalism from the Founders Republic to the Middle Republic to the Modern Republic is to be found in the increase in the number of States from 13 to 34 to 48 and now 50. Our argument helps explain the dissolution of federalisms and nations in the U.S.S.R., Yugoslavia, Czechoslovakia, and the tension experienced in federations like Canada with 10 Provinces and Belgium with two language groups. Federations of 26 cantons and half cantons like Switzerland or of 27 nations like the EU seem to be quite stable as systems of dual federalism. Once the number of federal subunits hits the high 30's or 40's dual federalism ends and is replaced by national omnipotence.

\section{Pluralism and Civil Rights}

A fourth argument for national and international power has its origins in a debate that went on in 1787 and 1788 during the ratification process for the U.S. Constitution. Opponents of the Constitution, who called themselves the Anti-Federalists, argued that democracy was only possible in small city States like Athens and Rome before it acquired its empire. The claim was that government had to be kept close to the source of 
its power (the people) to reduce agency and monitoring costs. Direct popular participation in governments that were larger than city States was obviously not feasible in the $18^{\text {th }}$ Century given the then available technologies. Moreover, the American Framers' one experience with federalism through membership in the British Empire had soured them on the feasibility of making a distant imperial government responsive to democratic preferences in the provinces.

James Madison responded to this argument with his now famous argument in the Tenth Federalist paper - the genius of which has only come to be appreciated in modern times. The discussion that follows draws from the author's law student Note in the Yale Law Journal published 27 years ago. ${ }^{24}$ As explained there, Madison argued in Federalist 10 that the gravest threat to democracy came from violent factional conflicts. In saying this, he was undoubtedly thinking of the religious wars in Seventeenth Century England among Anglicans, Catholics, and Puritan dissenters as well as the fights among merchants, farmers, investors, and debtors which were then plaguing the U.S. Madison argued that federalism would help solve one of the key problems of democracy which was the risk of a tyranny of the majority. Such a tyranny occurs, according to Madison, when an entrenched majority faction consistently decides an issue or a set of issues unjustly for its own self interested benefit. Madison thought that "[t]he latent causes of faction ... [were] sown in the nature of man," but that they were aggravated in small democratic city states where one monolithic faction or alliance of factions could entrench itself and abuse the minority. Madison identified two structural features of the Federal

24 Steven G. Calabresi, “A Madisonian Interpretation of the Equal Protection Doctrine,” 91 YALE L. J. 1403 (1982). 
Government that he believed would make majority tyranny less likely at the federal level than it had been in the 13 States.

First, Madison argued that a federal Republic of 13 States would have a much greater variety of interest groups and factions than would any one of the States alone. This increase in the number and variety of factions, Madison argued, would make it harder for a permanent tyrannical majority coalition to form and to endure at the national level as compared to the State level. The many factions in national majority coalitions would have different interests that would be likely to conflict over time. As Madison predicted, national leaders have, in fact, had trouble designing the compromises necessary to hold such coalitions together. FDR's New Deal coalition ultimately broke apart over civil rights when southern and northern democrats went their separate ways, a process that was evident as early as the midterm elections of 1938 . The Reagan Revolution ultimately foundered when social and economic conservatives went their own way, a process that was evident when the popular Reagan could not get social conservative Robert Bork confirmed to the Supreme Court.

Ultimately, the difficulty of maintaining a permanent majority coalition in Congress has proven to be similar to the difficulty groups like OPEC face in maintaining a large, multimember cartel. Like such cartels, majority coalitions in Congress usually have more members than their leaders can keep happy at the same time. Some of those members thus find themselves inevitably led by their own self interest to seek new and more promising allies. Southern Democrats thus defected out of the New Deal coalition over the civil rights issue just as socially liberal suburban Republicans defected out of the Reagan coalition over social issues. The result is that national majority coalitions of 
factions or special interest groups are hard to form and even harder to hold together over time. Such national coalitions are unlikely to harden into entrenched majority and minority blocks. Self interest and the stunning variety of factions in a large federal republic prevent any one group from monopolizing the political marketplace.

At the State level, however, the smaller number of factions facilitates the forming of entrenched majority coalitions. Just as cartels form most easily in homogenous markets with few producers, entrenched majority coalitions form most easily in homogenous legislatures with few factions. The more competitive or fluid the environment, the more difficult cartelization becomes. Competitive environments with large numbers of dissimilar factions quickly wear down any entrenched majorities.

The fact majority coalitions are less stable at the federal than at the State level means that consistent tyranny by the same majority of the same minority is less likely at the federal level. Congressional leaders will often be in need of the votes of those sympathetic to minority rights in the future so they will have more of an incentive to treat minorities fairly. The political processes at the federal level are thus less likely to be curtailed by the kind of prejudice which John Hart Ely wrote about in Democracy and Distrust. ${ }^{25}$ Indeed, by forcing national congressional leaders to bid for their support, minority groups in Congress may acquire the political leverage of single issue voters. They may find themselves able to extract political concessions in Congress that they could never have obtained at the State level. The larger number of factions at the federal level and the instability this causes in congressional coalitions thus benefits minorities by making prejudice more costly and less likely at the federal level than at the State level.

\footnotetext{
${ }^{25}$ John Hart Ely, Democracy AND Distrust: A Theory of Judicial ReVIEW (1980).
} 
A second feature of the national government that works to protect minority rights involves the large numbers of people who must be brought together in a large democracy to form a popular majority coalition. As Mancur Olson long ago pointed out ${ }^{26}$ and as Madison anticipated, large numbers create a communication problem by making it hard for would-be oppressors "to discover their own strength and to act in unison ...."27 As Madison foresaw, communication and organizational costs are comparatively lower for discrete and insular minorities than for large amorphous groups. Richard Nixon's famous silent majority was silent because it was expensive to communicate. The very cohesiveness of minorities, their discreteness and insularity, make it more expensive and less likely for majorities to organize than for special interest groups to organize. ${ }^{28}$

As the size of a polity expands, this organizational advantage that minorities have over majorities becomes even more pronounced. Of course, modern communications technologies have greatly lowered the costs to majorities of organizing and communicating, but they have correspondingly lowered those costs for minorities and factions as well. The development of first conservative talk radio and then of the internet sites that supported the Obama campaign illustrate this vividly.

Madison's variety of interests argument and his organizational costs argument are, of course, interdependent. Low organizational costs for minority factions in Congress would be useless if that body were dominated by a stable majority coalition. State legislatures may be so dominated and may leave little room for minorities to exploit their organizational advantage. At the same time, the instability of congressional

\footnotetext{
${ }^{26}$ OLSON, supra note 9.

${ }^{27}$ The FedERAlist No. 10 (James Madison).

${ }^{28}$ See George J. Stigler, The Theory of Economic Regulation, 2 BeLl J. ECON. MGT. SCI. 1, 12 (1971) (noting that small minorities with strong preferences find the costs of procuring favorable regulation lowest).
} 
coalitions would not help minorities much if they could not afford to organize more easily than the majority. It is for this reason that large amorphous groups like taxpayers, whose organizing costs are high, lose out all the time to special interest rent seekers.

The political influence and organizational strength of minorities at the federal level together lead to better protection for minorities in Congress than in the State legislatures. This has historically been true for the minority of property owners at the Founding, for African Americans, and for crony capitalist rent seekers alike throughout American history. The very discreteness and insularity that render minorities vulnerable at the State level accords them power disproportionate to their numbers in the federal legislative process. Whereas State procedure and structure reinforce the tendency of majorities to tyrannize minorities, federal procedure and structure weaken any such tendency. Thus, "[i]n the extent and proper structure of the Union ... we have beheld a republican remedy for the diseases most incident to republican governments."29

How did the expansion of the Federal Government from a league of 13 States on the Atlantic seaboard in 1790 to a league of 34 States stretching to the Pacific Ocean to a league of 48 States encompassing much of North America affect the normative case for national power? Obviously, this expansion increased the number and heterogeneity of interest groups represented in Congress and in other federal institutions. A transcontinental democratic empire engaged in extensive global trade with many religious and ethnic subgroups has many more interests groups than the U.S. did in 1790 and those interest groups will differ more from one another. The formation of permanent majority cartels in Congress thus ought to be harder now than at the Founding and special interests ought correspondingly to be more powerful.

\footnotetext{
${ }^{29}$ The Federalist No. 10 (James Madison).
} 
Of course, the States too have grown in population and several new and very large States have been admitted to the Union like California, Texas, and Florida. These megaStates, more populous by far than the whole U.S. in 1790, will according to Federalist Ten be less prone to majority tyranny than say Rhode Island. But compared to the vast Federal Government, even mega-States like California, Texas, and Florida will be easier for majorities to capture and to hold than will be Congress. It is striking in this regard that Republicans at this writing appear to have a lock on the governorship, State senate, and State house of representatives in Texas and Florida while Democrats have a lock on the State legislature in California and an ally on most issues in the governor's office. In all three States, Republican and Democratic voting patterns correlate strongly with race, ethnicity, and gender. Majority tyranny is more likely even in mega-States than it is at the federal level, and it is much more likely in States that are geographically small like Rhode Island or that have low populations like Wyoming.

What if the current geographical territory of the U.S. were divided among only four regional mega-State or only 10 Provinces, as in Canada? We saw above that costs to the States of secession and of resistance to federal power would go down, but what would the picture look like for civil rights protection? In a U.S. federation, of four mega-States - the Northeast, the South, the Midwest, and the West - one would expect more tolerance at the State level than we see today or have seen over the course of American history. Four large, heterogeneous States will be less likely to be dominated by entrenched majority tyrannies than were 34 in 1861 or 48 in 1912. Still, one cannot help wondering in such a 4 State U.S. federation how African Americans would fare in the South or how devoutly religious Americans with traditional values would fare in the Northeast? In the 
West, California's politics have in recent years been roiled by bitter warfare over cultural/religious and racial ethnic issues. Our intuition is that the current transcontinental U.S. federation would do a better and fairer job of avoiding entrenched majority tyrannies than would even a 4 mega-State federation occupying the same territory.

The U.S., of course, did not go down the 4 mega-State road having opted instead for a large number of smaller States starting with the Northwest Ordinance in 1787. What are the consequences for the normative case as to civil rights protection of the fact we went from 13 States in 1790 to 34 in 1861 to 48 in 1912 to 50 today? Does the fact that the expansion in the number of States coincided with our adding new territory and immigrants mitigate any increased likelihood of majority tyranny at the State level? It seems likely that the addition of territory and of immigrants means that the States as a whole are not less diverse today than they were in 1787 . Indeed, there are almost certainly more factions in present day Virginia or Rhode Island than there were in the 1790s. Moreover, some new States like Arizona are very heterogeneous even if others like Wyoming are less so.

Still, the press and politically active pundits must monitor 50 State governments today for civil rights violations, instead of 13 , undoubtedly allows abuses to go unpunished. Moreover, Congress today represents a far greater variety of factions than it did 220 years ago. The Federalist Ten Case for enhanced national power because such power reduces the danger of majority tyranny is thus stronger today than it was at the founding. And, it is stronger in a Union of 34 or 48 or 50 States than it is in a Union of 4 mega-States occupying the same territory and including the same population. The greater 
the number of States, the more federal civil rights law one might expect to see. Thus, it is no surprise that Congress passed the first civil rights law in 1866 when the Union had 36 States; the Supreme Court began incorporation of the Bill of Rights in 1897 when we had 45 States and finished it once we were up to 48 and then 50; and that Congress, since we have had 50 States has legislated extensively to protect civil rights at the national level. Even the appearance of federal judicial invention of unenumerated civil rights against the States in Lochner in 1905 and in Griswold v. Connecticut in 1965 fits with this picture.

The bottom line is that increasing the number of States from 13 to 50 just by itself makes federal civil rights law more desirable and likely even without factoring in an addition of land and people.

\section{The Number of States and the Case for Augmenting State Power}

We want here to consider three economics of federalism arguments for augmenting State power in federations: first, that augmenting State power allows a better tailoring of laws to varying tastes, conditions, and preferences; second, that augmenting State power will lead to enhanced competition and experimentation; and third, that augmenting State power will lead to lower monitoring costs. We address each point in turn by relating it to the change we have experienced as a resulting of moving from 13 to 50 States.

\section{A. Varying Tastes, Conditions, and Preferences}

A standard pro-State power economic argument is that tastes, preferences, and conditions vary across the States in a federation. Montana has different needs with 
respect to a speed limit than does New Jersey. Louisiana and Utah have different preferences as to abortion than California or New York. By devolving some power from the national to the sub-national level, constitution writers can hope to maximize social welfare and utility. More people will be happier if there is no national speed limit or abortion policy, and the diverging policies that result may be better tailored to real differences among the State and their peoples. A 55 mile per hour speed limit in Montana may not make sense because of the large size and low population density of that State.

The argument that tastes, conditions, and preferences vary geographically is a powerful argument for State power in the U.S., for Provincial power in Canada, and for real subsidiarity and member nation power in the European Union. How is that argument affected if a federation has a larger number of States say 48 as opposed to a small number occupying the same geographical area and having the same population? A continental United States divided up among 48 States, as existed after 1912, rather than say 4 megaStates would in theory be able to do a better job of tailoring laws to local tastes, preferences, and conditions - assuming the national government's power and role stayed the same (which it would not). The larger the number of territorially defined States within the same geographical area and with the same population, the greater the ability to tailor State laws exquisitely and uniquely to each State’s different tastes, conditions, and preferences. This particular policy argument for federalism or devolution becomes stronger as the number of States increases even as it becomes less likely that States will secede or have real political power at the national level. 


\section{B. Competition or Experimentation Among the States}

A second and related economic argument for federalism and State power is that in a federation the member States will compete with each other for taxpayers, for industry, for the highest standard of living, and in providing the optimal governmental bundle of public goods. ${ }^{30}$ This competition among States will in turn spur experimentation. States will become laboratories of democracy, as Justice Brandeis argued, competing with one another to offer their voters the optimal bundle of public goods. ${ }^{31}$ Thus, federalism not only allows for laws to be tailored to different tastes, conditions, and preferences, but it also sets in place ideally a free market of bundles of public goods. ${ }^{32}$ Citizens and business will vote with their feet for the optimal bundle, and States will experiment and compete vigorously with one another as a result.

There are powerful arguments for State power, devolution, and subsidiarity, but how are they affected by increasing the number of States in a federation from 13 to 34 to 48? The answer, we submit, is evident from Antitrust Law which tells us that a free market with 48 players will be more competitive and will lead to more experimentation and innovation than a market with 34 or 13 players. As the number of players goes up, the market share of the largest players will be likely to go down, and the ability of the players to coordinate their activities voluntarily to form a cartel on their own will go down too. Even when the States form a voluntary cartel that cartel is less likely to prove to be stable in a 48 member federation than in a 13 State member federation because it is more likely that a State will defect and cheat on the cartel. One would expect more

\footnotetext{
${ }^{30}$ Charles Tiebout, A Pure Theory of Local Expenditures, 64 J. Pol. Econ. 416 (1956).

${ }^{31}$ New State Ice Co. v. Liebmann, 285 U.S. 262 (1932) (Brandeis, J., dissenting).

${ }^{32}$ See Yingyi Qian \& Barry R. Weingast, Federalism as a Commitment to Preserving Market Incentives, 11

J. Econ. Perspectives 83 (1997).
} 
bracing and vigorous competition among the States and also experimentation therefore as the number of States in the Union goes up.

Unfortunately, all that competitive pressure is also likely to lead to more and more calls for federal help in forming and policing cartels since government is the best monopolist on the block. One would therefore expect more and more calls for central government "standard setting" as the competition among the States gets more intense. This, of course, is exactly what happened over the course of American history. When the number of States hit the mid-thirties, we got the federal floor as to standards set by the $13^{\text {th }}, 14^{\text {th }}$, and $15^{\text {th }}$ Amendments. When the number of States hit 45 we began to get incorporation and Lochnerian substantive due process. By the time we got to 48 States in 1912, the constitutional dam broke and we got the $16^{\text {th }}$ and $17^{\text {th }}$ Amendments which enormously empowered the Federal Government. The Supreme Court held out for the old constitutional order for 25 years after 1912 thanks to Taft and Harding appointing 10 justices in 7 years while Teddy Roosevelt and Woodrow Wilson appointed only 6 in almost 16 years, but by 1937 the game was up. After 1912, the competition among States came to be viewed by our legal and academic elites as a race to the bottom which could only be stopped by a federal cartel. From the New Deal on, this perception has carried the day, and so it can be correctly said that the competition among the States was so successful that it may have helped to lead to the end of American federalism.

\section{Lower Monitoring or Agency Costs}

Another good economics of federalism policy argument for devolving power to the States is that the people will experience lower costs monitoring their politicians in 
smaller democracies and that the people will be better able to rein in their elected agents. $^{33}$ In theory, assuming national and State politicians received comparable press coverage, which they do not, voters ought to be able to monitor better their elected State officials because they are closer to home, easier to meet with and see, more likely to be a neighbor, and just generally more accessible. Enhanced monitoring, in turn, ought to lead to lower agency costs. State elected officials should in theory be on a shorter leash than federal officials, assuming equal media coverage, comparable ethics, and criminal penalties for misconduct.

How does increasing the number of States affect monitoring and agency costs? It ought quite obviously to lower such costs. If we disallow for differences in media coverage and in legal sanctions for misconduct, it ought to be easier to monitor State officials in more and smaller States than in a few bigger States. It is presumably easier to monitor the governor of Rhode Island or Alaska than it would be to monitor a governor of all the Southern States, for example. Thus, again the argument for State power federalism, or for devolution, or for subsidiarity in the EU becomes stronger as the number of subparts in a federation increases. Federations with lots of subparts will experience lower monitoring and agency costs than federations with fewer subparts. Since monitoring and agency costs were among the reasons why the U.S. declared its independence from the British Empire in 1776, this conclusion ought certainly to be of interest.

\footnotetext{
${ }^{33}$ See, generally, ANTHONy Downs, An ECONOMIC THEORY OF DEMOCRACy (1957) (on rational ignorance and information costs in voting).
} 


\section{What is the Optimal Number of States?}

A. The Number of States and Interest Group Pressure

Although not as frequently mentioned as the salutary effect of federalism in curbing the influence of faction, the analysis in Federalist 10 suggests a malign aspect as well. When the size of a federal system grows, it presents greater opportunity for widely dispersed but well organized groups to apply pressure at the federal level that they would be unable to apply in the States. Indeed, the externalities and competition discussed above encourage a shift of rent seeking from the local to the national stage. Were any faction to prevail in one State, it would face competition from other States with more robust markets. The rent-seeking effort of the faction in the first State would create positive externalities for competitors in other States, presenting the classic free-riding problem that is the bane of all interest groups. ${ }^{34}$ To solve this problem, interest groups can organize at the Federal level, but this tends to expand the scope of the national power over the States. As the number and interconnectedness of the several States increased, so too did factional demands for expanded Federal regulation.

Beginning with the fundamental insight of the Tiebout model, federalism is rightly seen as promoting efficiency in government through competition. ${ }^{35}$ When States must compete for labor and capital (and tax revenue), they are acting as producers of bundles of government in a competitive market. If they provide a bundle that consumers (in this case citizens and capitalists) demand, then they will prosper. If they offer corruption and waste, they will not. In essence, consumers of government will vote with

\footnotetext{
${ }^{34}$ See George J. Stigler, The Theory of Economic Regulation, 2 BeLl J. ECon. MGt. SCI. 1, 12 (1971) (noting that small minorities with strong preferences find the costs of procuring favorable regulation lowest).

${ }^{35}$ Tiebout, supra note 30.
} 
their feet as well as their ballots. Of course, this rosy image of efficiency and prudent government depends on effective competition and the mobility of both investment capital and some relevant segment of the population. Riker further refined this analysis by developing the conditions for a self-enforcing federalism, which requires that the hierarchical levels of government be autonomous and of limited scope. ${ }^{36}$ However, even this addition will only perpetuate some form of federalism, rather than the particularly desirable competitive market form of federalism that the Tiebout model envisions. To ensure a market-preserving federalism, Weingast added three additional conditions: a national market, a hard budgetary constraint at the State level, and a division of powers that places primary responsibility for economic policies at the State level. ${ }^{37}$ The first two conditions are constitutionally provided ${ }^{38}$ and uncontroversial; the third is the linchpin of the analysis. It is here that the number of States becomes an issue of concern.

In a federation of thirteen States with relatively limited interstate commerce, the natural locus for the provision of economic regulation is the State. When the number of States, the size of the federation, and the amount of commerce increase, regional regulation through informal agreements becomes more efficient. Increase the size yet further, and national regulation becomes more attractive. This is a result of several forces. First, transaction costs increase at an exponential rate as the number of relevant bargaining parties grows. Second, economies of scale are realized through standardization, which produces greater benefits as the number of potential standards

\footnotetext{
${ }^{36}$ WiLliam RiKER, FEDERALISM: ORIGIN, OPERATION, AND SiGNIFICANCE 11 (1964).

${ }^{37}$ Weingast, supra note 7.

${ }^{38}$ U.S. CONST. art. I $§ 2$ (prohibiting States from coining money or imposing duties).
} 
increases. ${ }^{39}$ Third, externalities from economic activity in one State are likely to be increasingly felt in other States as the number of States increases. ${ }^{40}$ Fourth and finally, the increasingly competitive government market between States forces factions to seek economic rents through Federal regulation. ${ }^{41}$

This last force for centralization of economic regulation deserves particular consideration. The other forces are discussed above, and all lead to the conclusion that an increase in Federal power as the number of States increased merely maintained an optimal division of powers between the levels of government in our system. They offer the benign explanation for consolidation and expansion of government power. The influence of interest groups offers the malign explanation. It is this, above all, that suggests that having too many States leads to an excessive centralization of government and disrupts the vertical balance of powers in a federal system. The economics of federalism analysis explains why the balancing point has shifted in favor of national power; the interest group analysis suggests there is a thumb on the scales.

As Madison recognized in Federalist 10, an "extended republic" will indeed "break and control the violence of faction" on the State level by introducing countervailing interests. ${ }^{42}$ However, the transaction costs of organizing majority

\footnotetext{
${ }^{39}$ It is interesting to note the development of the major interstate commerce facilitating actions by the Federal Government. First, the Bank of the United States solved a fundamental problem of financing transactions across great distances. Second, the Interstate Commerce Commission solved a problem of transportation efficiency after the advent of the railroads. Third, the Securities and Exchange Commission solved a problem of information disclosure with respect to investments in an increasingly national market. Fourth, the Federal Communications Commission removed telecommunications from the ICC jurisdiction when such interstate communications became increasingly widespread and complex.

${ }^{40}$ This is the down side of experimentation. As the number of States grows, the potential for externalities increases if for no other reason than the proliferation of (potentially externality-generating) policies. Holding the probability of externality generation constant, more policies in force should lead to more externalities, on average.

${ }^{41}$ Peter H. Aranson, Federalism as Collective Action (Mar. 29, 1995) (unpublished manuscript, on file with author).

${ }^{42}$ The Federalist No. 10 (James Madison).
} 
opposition to cohesive minority rent seeking will grow as the number of States and the size of the nation increase. ${ }^{43}$ This results from the principal problem of organizing interest groups: free riding. ${ }^{44}$ With respect simply to the number of States, an increase in States leads to an increase in competition under the Tiebout model. This then has the perverse effect of altering the calculus of interest groups in favor of Federal rent seeking, rather than State rent seeking. ${ }^{45}$ Precisely because of competition between the States, interest groups find greater benefit in pursuing national regulation. ${ }^{46}$ This then encourages an expansion of the central government at the expense of the State governments in the area of economic regulation, which undermines one of the conditions for self-enforcing market-preserving federalism. ${ }^{47}$ It also systematically skews the balance of power away from the States and toward the Federal Government.

By expanding from thirteen to thirty-four to fifty States, the United States has seen the balance of power shift in favor of centralization. The previous sections have explained in detail how this has resulted quite naturally and benignly from necessity of changed circumstances. Assuming diminishing marginal returns to the advantages of State level government (competition and experimentation, agency costs, and adherence to local preferences) and the advantages of Federal level government (economies of scale, elimination of collective action problems, internalization of externalities, and the protection of minority interests through countervailing factions) as the number of States increases, there should be an equilibrium between State and Federal power that maximizes the net value of government. There should also be a number of States that is

\footnotetext{
${ }^{43}$ Aranson, supra note 41.

${ }^{44}$ See, generally, Mancur Olson, Jr., The Logic of Collective Action (1965); Stigler, supra note 34.

${ }^{45}$ Aranson, supra note 41.

${ }^{46}$ Id.

${ }^{47}$ See Weingast, supra note 7.
} 
optimal - large enough for cohesion but small enough for true competition between the States. As the number of States increases, the advantage Madison ascribed to the "extended republic" of checking majority factions will begin to tip toward facilitating rent seeking by minority factions. Just as the benign aspects of the economics of federalism suggest the benefit of more States in limiting rent seeking by interest groups, the malign aspects suggest the benefit of fewer.

\section{B. Implications - When Is Enough Too Many?}

Our analysis thus far suggests that all the economics of federalism policy arguments both for national and for State power in the U.S. become more telling as the number of States increases. The 50 United States today need a national government more than would a 4 State federation in the same geographical territory because of collective action problems with respect to: 1) war and foreign affairs; 2) free trade; 3) correcting externalities imposed by State action; and 4) reaping the benefits of economies of scale. The 50 United States also need a national government more today than would a 4 State federation to protect civil rights and guard against tyranny of the majority.

On the other hand, a 50 State federation is more likely to allow for tailoring laws to suit for differences in local tastes conditions, and preferences than would be a 4 State federation. A 50 State federation will also do more to promote vigorous competition and experimentation among its members which will have the negative side effect of increasing demands for federal floor setting or cartelization. Finally, a 50 State federation may benefit from lower monitoring and agency costs. 
All of these arguments suggest that when a federation expands from 13 to 34 to 48 States it gets more of both the good and the bad things that come with having a federal as compared to a unitary constitutional structure. Ironically, 50 State competitive federalism may be potentially much better than 25 State competitive federalism, but it is also probably impossible politically to sustain because of the way in which State power is weakened when the number of States expands and because the competition among 50 States and the collective action problems and externalities of a 50 State federalism produce unstoppable demands for national floor setting or cartels. If this argument is correct, it is hard to see how American federalism today could realistically be revived in any meaningful way. Once the number of U.S. States went from 38 to 44 in 1889-1890, the retention of any kind of meaningful American federalism was probably doomed.

The immediate temptation, of course, is to conclude that to reap the benefits theoretically available from federalism one ought to opt for a much smaller number of federal subunits like Canada's 10 Provinces or the 13 original States. This argument fails, however, because it overlooks the enormous danger of secession and civil war that comes along with a small State federalism as well as the likely weakening such a federalism would have on the power of the national government. Some federations like the 6 State Australian federation of course work just fine, but the dissolution of the 15 Republic U.S.S.R., or of the 6 Republic Yugoslav federation, or of the two region regimes in Czechoslovakia and possibly Belgium all raise major concerns. An interesting question in this regard is when did it become politically too hard for the slave owning American South to secede from the Union. History tells us that it could not be done once the Union had hit 34 States in 1861, but it might still have been possible at the time of the 
Nullification Crisis when we had only 24 States - half of them slave States - had not an implacable Andrew Jackson have stood in the way. Any number of federal subunits below 20 and possibly below 15 might thus be so low as to raise fears of secession depending critically of course on the territorial distribution of racial, ethnic, linguistic, religious, and economic cleavages.

The mid twenties looks in many ways like an optimal number of subunits for maintaining a balance of power, a federal structure, and reaping the benefits of the economics of federalism. Switzerland with its 26 cantons and half cantons and the European Union with its 27 member nations may thus be at the optimum point around now if one wants to create what the Supreme Court famously called "an indestructible Union, composed of indestructible States." ${ }^{48}$ Further expansion of the EU might thus be a mistake that leading member nations ought to guard against unless they actively want to see the European nation States disappear altogether. An EU federation might survive with larger numbers of subunits than did American federalism because of the long histories, separate languages, and distinctive subcultures of the EU member States as compared to the 50 American States. At some point that is not that far off, however, the number of subunits will make all efforts to maintain subsidiarity impossible.

Moving beyond the federalism of the European Union, we should note the tremendous spotlight of public attention that President Obama just shined on the G-20 - a group of twenty nations from all over the world that are interconnected economically and are global leaders. For the first time, the G-20 received the kind of media attention normally reserved for meetings of the G-8. The G-8 for the record consists of: Canada, France, Germany, Italy, Japan, Russia, the United Kingdom, and the United States, while

${ }^{48}$ Texas v. White, 74 U.S. 700, 725 (1868). 
the G-20 includes 11 nations in addition to these 8 and the European Union: Argentina, Australia, Brazil, China, India, Indonesia, Mexico, Saudi Arabia, South Africa, South Korea, and Turkey. Elevating the visibility and role of the G-20 and delegitimizing the G-8 is a shrewd way for the U.S. to play giants like India, China, Brazil, and Argentina off against our enemies in the Islamic world and possibly in Russia. This essay suggests reasons to be more bullish about the prospects for success in the G-20 than in the G-8.

Our bottom line is that the wealth of nations is enhanced by federalisms with a healthy balance between national and State power and that in turn depends on the size of nations and in this case Federations. The optimal number of subunits for a balanced federalism is probably somewhere between about 18 and 34, although there will be occasional exceptions like 6 State Australia. Even Canada with only 10 Provinces has not broken apart - at least not yet. Federalists of the World Unite! But only in confederacies of between 18 and 34. 